\title{
IMPLEMENTASI PERATURAN DAERAH KABUPATEN JEMBER NOMOR 6 TAHUN 2008 TENTANG PEDAGANG KAKI LIMA
}

\author{
RAHMAWATI DARMANINGSIH \\ HIMAWAN BAYU PATRIADI \\ EDY WAHYUDI* \\ Program Studi Magister Ilmu Administrasi \\ Fakultas Ilmu Sosial dan Ilmu Politik \\ Universitas Jember \\ *Email: edydata75@gmail.com
}

\begin{abstract}
ABSTRAK
Tulisan ini membahas tentang administrasi publik khususnya tentang implementasi kebijakan publik. Kasus yang akan diteliti adalah permasalahan Pedagang Kaki Lima.

Jenis penelitian yang dilakukan adalah kualitatif. Metode kualitatif digunakan dengan pertimbangan bahwa peneliti bermaksud untuk mendeskripsikan atau memperoleh gambaran secara leluasa tentang Implementasi Peraturan Daerah Kabupaten Jember Nomor 6 Tahun 2008. Lokasi penelitian di Kabupaten Jember tepatnya tiga kecamatan kota yaitu Kecamatan Kaliwates, Kecamatan Sumbersari, dan Kecamatan Patrang.

Implementasi Peraturan Daerah Kabupaten Jember Nomor 6 Tahun 2008 tentang Pedagang Kaki Lima dikatakan kurang berhasil, karena masih ada pedagang kaki lima yang kembali ketempat semula setelah direlokasi ataupun mereka tidak mau pindah secara sukarela meskipun sudah disediakan tempat relokasinya sehingga memaksa aparat Satuan Polisi

Pamong Praja beserta Tim Penataan pedagang kaki lima mengambil langkah represif. Penyebab terjadinya hal tersebut adalah belum tersedianya tempat relokasi dengan segala aksesnya, yang menjadi tanggung jawab Dinas Cipta

Karya dan Tata Ruang, dan belum diadakan pelatihan-pelatihan kepada pedagang kaki lima agar dagangan mereka lebih menarik tampilan maupun rasanya, ini menjadi tanggung jawab Dinas Perindustrian dan Perdagangan.
\end{abstract}

Kata Kunci: Pedagang Kaki Lima, Satuan Pamong Praja, Peraturan Daerah, Dinas Cipta Karya dan Tata Ruang 


\section{PENDAHULUAN}

Pedagang Kaki Lima (PKL) adalah fenomena besar di Indonesia baik di kota-kota besar seperti Jakarta, Surabaya, dan Semarang maupun di kota- kota kecil layaknya Banyuwangi, Situbondo dan Jember. Keberadaan PKL sebagai sektor informal merupakan bagian yang sebenarnya memiliki ketahanan cukup handal dibandingkan sektorsektor usaha lainnya. Terbukti di saat sektor-sektor usaha lain tersingkir akibat badai krisis moneter, justru sektor ini tumbuh dan berkembang hampir di setiap kota.

Kehadiran para PKL disatu sisi diharapkan membuat perputaran roda perekonomian berjalan lancar dan mengurangi angka pengangguran. Namun disisi yang lain kehadirannya menimbulkan berbagai macam masalah, karena para PKL menempati ruang publik untuk berjualan sehingga aktivitas dan kenyamanan masyarakat terganggu. Masalah lain yang tidak kalah pentingnya adalah mereka berjualan untuk pemenuhan kebutuhan atau mencari nafkah bagi keluarga, dengan kata lain kegiatan ini dilakukan karena menyangkut masalah perut. Meskipun demikian, keberadaan PKL mempunyai tingkat kerentanan yang cukup tinggi manakala tidak mendapatkan penanganan yang serius dari pemerintah.

Sektor informal biasanya digunakan untuk menunjukkan aktivitas ekonomi berskala kecil dan sering mengalami banyak kesulitan untuk menjalin hubungan secara resmi. Sektor informal yang dimaksud disini adalah suatu kegiatan berskala kecil yang bertujuan untuk mendapatkan kesempatan kerja. Pada umumnya elemen yang termasuk dalam sektor ini adalah yang berpendidikan kurang, kurang terampil dan kebanyakan merupakan para pendatang dengan cara berdagang kecil-kecilan atau kita biasa sebut dengan nama PKL.

Lokasi berjualan PKL selalu menempati lahan atau ruang publik misalnya trotoar, bahu jalan, tamantaman kota, tempat-tempat disekitar pusat perbelanjaan, kawasan perkantoran, tempat-tempat yang 
ramai dikunjungi orang dan tempattempat strategis lainnya. Jika satu pedagang tidak langsung ditertibkan maka hampir bisa dipastikan pedagang yang lain akan bermunculan bagai jamur dimusim hujan. Ini semua akan menimbulkan gesekan-gesekan diantara PKL dengan aparat Satuan Polisi Pamong Praja (Satpol PP), dan antara PKL dengan masyarakat sebagai pemanfaat ruang publik.

\section{Dasar pertimbangan} pembentukan peraturan daerah tersebut, bahwa pertama, PKL sebagai individu warga masyarakat perlu diberikan kesempatan untuk mengembangkan usahanya dalam rangka mendukung perkembangan ekonomi sektor informal. Kedua, dalam perkembangannya, keberadaan PKL di kawasan perkotaan Kabupaten Jember telah menggunakan bahu jalan, trotoar atau fasilitas umum yang dapat menimbulkan gangguan ketentraman, ketertiban, kebersihan lingkungan, dan kelancaran lalu lintas sehingga perlu dilakukan pembinaan dan pengawasan yang terarah agar tercipta tertib sosial.
Untuk itu dalam rangka pembinaan dan pengawasan terhadap PKL secara terarah dan terciptanya tertib sosial maka Satpol PP sebagai kepanjangan tangan pemerintah daerah dalam penegakan peraturan daerah dan penyelenggaraan ketertiban umum dan ketenteraman masyarakat yang kemudian bekerja sama dengan unsur pemerintah dan masyarakat yang selalu berpedoman pada Peraturan Menteri Dalam Negeri Republik Indonesia Nomor 41 Tahun 2012 tentang Pedoman Penataan dan Pemberdayaan Pedagang Kaki Lima, Peraturan Daerah Nomor 6 Tahun 2008 tentang Pedagang Kaki Lima Kabupaten Jember dan Peraturan Bupati Nomor 36 Tahun 2009 tentang Penataan Pedagang Kaki Lima Kabupaten Jember. Permasalahan tentang PKL telah dituangkan dalam Dokumen Pelaksanaan Anggaran (DPA) SKPD Satuan Polisi Pamon Praja Kabupaten Jember dalam program Pemeliharaan Kantrantibmas dan Pencegahan Tindak Kriminal, ada dua kegiatan didalamnya yaitu: a) Pemantauan pelanggaran perda; dan 
b) Pengamanan pejabat dan Asset Pemkab.

Masalah PKL di Kabupaten Jember adalah jumlahnya yang semakin lama semakin bertambah (saat ini PKL yang berada di wilayah kota berjumlah sekitar 1.211 PKL terbagi dalam dua shift yaitu siang dan malam), yang tersebar di di Jl Gajah Mada, Jl Talangsari, J1 Trunojoyo, J1 HOS Cokroaminoto, Jompo (Kecamatan Kaliwates) J1 Panjaitan, Jl Jawa, Jl Riau, J1 Kalimantan, Jl Sumatra, J1 Sumatra, J1 Mastrip, J1 Ciliwung, J1 Bengawan Solo, J1 Letjen Suprapto, J1 Letjen S. Parman (Kecamatan Sumbersari) Jl PB. Sudirman, Jl Moh. Sroedji, Jl Nusa Indah, Jl Wijaya Kusuma, J1 Anggrek, Jl Kacapiring, Jl Cempaka, J1 Slamet Riyadi (Kecamatan Patrang) (Sumber : wawancara dengan Kasubbid Pembinaan, Pengawasan dan Penyuluhan Satpol PP Kabupaten Jember, tanggal 2 Oktober 2015).

Masalah PKL bukan hanya masalah Satpol PP sebagai leading sector-nya, melainkan berkaitan dengan banyak instansi lain yang terlibat di dalamnya, oleh karena itu dibutuhkan sinergisitas dengan instansi lain dan untuk mewujudkan sinergisitas tersebut maka dibentuklah Tim Penataan dan Pembinaan Pedagang Kaki Lima (PKL) Kabupaten Jember dengan harapan menjadi salah satu solusi dalam rangka penataan dan pembinaan PKL kabupaten Jember. Tim penataan dan pembinaan PKL Kabupaten Jember berdasarkan Keputusan Bupati Jember Nomor 188.45/107/012/2015 yang terdiri dari unsur pemerintahan dan masyarakat yaitu Muspida, Wakil Bupati, Sekretaris Kabupaten, Asisten Pemerintahan, Kepala Satuan Polisi Pamong Praja, Kepala DPU Bina Marga, Kepala DPU Cipta Karya dan Tata Ruang, Kepala Dinas Perhubungan, Kepala Dinas Pasar, Kepala Bagian Hukum, Kepala Bagian Humas, Kabag Operasional Polres Jember, Perwira Seksi Operasional Kodim 0824, Kabid Penegakan Perundangundangan Satpol PP, Kasi Pembinaan, Pengawasan dan Penyuluhan Satpol PP.

Adapun tugas dari tim penataan dan pembinaan PKL antara lain: 
melakukan penataan dan penertiban terhadap PKL yang permanen dan/atau tidak permanen dibadan jalan dan/atau trotoar; melakukan penataan dan penertiban bagi PKL baru; melakukan evaluasi dan pengawasan secara berkala terhadap PKL di wilayah kabupaten Jember

\section{TINJAUAN PUSTAKA}

Kebijakan publik merupakan kebijakan yang mengikat bagi publik sehingga kebijakan publik tersebut dibuat oleh lembaga yang memiliki kuasa atau kewenangan dalam membuat kebijakan publik. Lembaga tersebut dalam membuat kebijakan publik juga tetap harus memperhatikan keinginan publik karena kewenangan yang mereka miliki merupakan mandat dari publik atau rakyat. Dalam suatu pemerintahan yang baik atau good governance, pemerintah harus bisa membuat suatu kebijakan publik yang mencerminkan kepentingan rakyat banyak, sehingga rakyat dalam hal ini tidak merasa dirugikan atas lahirnya kebijakan publik itu sendiri. yang telah dilakukan pembinaan, penataan dan penertiban; mengantisipasi agar tidak muncul PKL baru; menindak dan menertibkan secara berkala bagi PKL yang telah dibina, ditata dan/atau ditertibkan tetapi masih tetap melakukan pelanggaran.

Definisi kebijakan publik menurut Chief J.O (dalam Wahab, 2005:5) adalah suatu tindakan bersanksi yang mengarah pada tujuan tertentu yang diarahkan pada suatu masalah tertentu yang saling berkaitan yang mempengaruhi sebagian besar warga masyarakat. Jadi kebijakan publik merupakan keputusan politik yang dibuat dan dikembangkan oleh pemerintah dan memiliki karakteristik sebagai keputusan politik yang dirumuskan oleh yang berwenang atau yang memiliki otoritas. Menurut Easton (dalam Agustino, 2006:42) yang disebut sebagai otoritas dalam sistem politik adalah para senior, kepala tertinggi, eksekutif, legislatif, para hakim, administrator, penasehat, para raja, dan sebagainya. Selain itu 
Easton juga menyebutkan bahwa mereka yang berotoritas dalam system politik guna memformulasikan kebijakan publik itu adalah orang-orang yang terlibat dalam urusan sistem politik seharihari dan mempunyai tanggung jawab atas suatu masalah tertentu, dimana pada satu titik mereka diminta untuk mengambil keputusan di kemudian hari yang diterima serta mengikat sebagian besar anggota masyarakat selama waktu tertentu. Jadi suatu kebijakan publik dibuat dari tahapan-tahapan yang diawali dengan formulasi kebijakan, implementasi, hingga pada evaluasi kebijakan.

Implementasi merupakan salah satu tahap dalam proses kebijakan publik dan dilaksanakan setelah sebuah kebijakan dirumuskan dengan tujuan yang jelas. Matter dan Horn (dalam Agustino, 2006:139) merumuskan definisi implementasi kebijakan yaitu tindakan-tindakan yang dilakukan baik oleh individuindividu atau pejabat-pejabat atau kelompok-kelompok pemerintah atau swasta yang diarahkan pada tercapainya tujuan-tujuan yang telah digariskan dalam keputusan kebijakan. Mazmanian dan Sabatier mengemukakan bahwa implementasi kebijakan adalah pelaksanaan keputusan kebijakan dasar biasanya dalam bentuk undang-undang namun dapat pula berbentuk perintahperintah atau keputusan- keputusan eksekutif yang penting atau keputusan badan peradilan, dan keputusan itu mengidentifikasikan masalah yang ingin diatasi, menyebutkan secara tujuan atau sasaran yang ingin dicapai dan berbagai cara untuk menstrukturkan atau mengatur proses implementasinya.

Dari definisi tersebut maka dapat dimaknai bahwa yang dimaksud dengan implementasi kebijakan meliputi kegiatan atau aktivitas yang memiliki tujuan atau sasaran kebijakan serta memiliki hasil dari kegiatan tersebut. Rangkaian kegiatan tersebut mencakup persiapan seperangkat peraturan lanjutan yang merupakan interpretasi dari kebijakan tersebut. Misalnya dari sebuah undang-undang muncul sejumlah peraturan pemerintah, keputusan presiden, 
maupun peraturan daerah, menyiapkan sumberdaya guna menggerakkan implementasi termasuk di dalamnya sarana dan prasarana, sumber daya keuangan, dan tentu saja siapa yang bertanggungjawab melaksanakan kebijakan tersebut, serta bagaimana mengantarkan kebijakan secara konkrit ke masyarakat. Implementasi kebijakan pada prinsipnya adalah cara agar sebuah kebijakan dapat mencapai tujuannya, tidak lebih dan kurang.

Untuk mengimplementasikan kebijakan publik maka ada dua pilihan langkah yang ada, yaitu langsung mengimplementasikan dalam bentuk program program atau melalui formulasi kebijakan derivate atau turunan dari kebijakan tersebut. Sebagaimana yang pernah dikemukakan oleh Grindle (dalam Agustino, 2006:154) bahwa keberhasilan implementasi diukur dari prosesnya dengan mempertanyakan apakah pelaksanaan program sesuai dengan yang telah ditentukan yaitu melihat pada action program dari individual project dan yang kedua apakah tujuan program tersebut tercapai. Kebijakan publik dalam bentuk undang-undang atau peraturan daerah adalah jenis kebijakan yang memerlukan kebijakan publik penjelas atau sering diistilahkan sebagai peraturan pelaksanaan. Kebijakan public yang bisa langsung dioperasionalkan antara lain keputusan presiden, instruksi presiden, keputusan menteri, keputusan kepala daerah, keputusan kepala dinas, dan lain-lain (Nugroho DW, 2004:158-160). Jadi implementasi kebijakan merupakan suatu upaya untuk mencapai tujuantujuan tertentu dengan sarana-sarana tertentu dan dalam urutan waktu tertentu. Proses implementasi kebijakan publik baru dapat dimulai apabila tujuan-tujuan kebijakan publik telah ditetapkan, programprogram telah dibuat dan dana telah dialokasikan untuk pencapaian tujuan kebijakan tersebut.

Dari empat model, terdapat dua model yang bisa menjelaskan mengenai Implementasi Peraturan Daerah Kabupaten Jember Nomor 6 Tahun 2008 terkait penataan PKL yaitu model George C. Edward III 


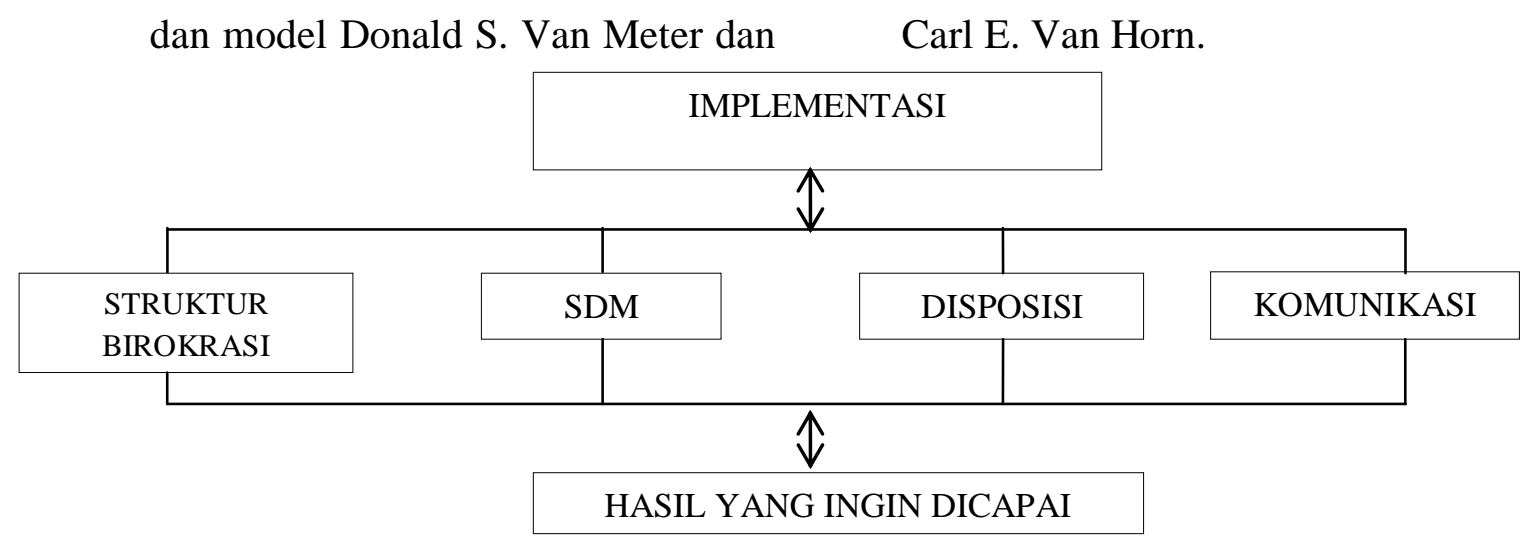

Gambar 1. Model Kebijakan Implementasi menurut George Edward III dalam Agustino (2006:156)

Dari Model Kebijakan Implementasi menurut Edward yang terlihat dalam Gambar 1 dapat dijelaskan bahwa terjadi hubungan timbal balik/saling mempengaruhi antara implementasi kebijakan publik dengan struktur birokrasi, sumber daya manusia (SDM), disposisi dan komunikasi. Keempat komponen yang disebut belakangan menjadi faktor penentu diputuskannya kebijakan publik. Sebaliknya, kebijakan publik yang telah diputuskan tersebut implementasi/penerapannya akan mempengaruhi cara kerja struktur birokrasi, SDM, disposisi, dan komunikasi.

Keempat komponen yang menjadi faktor penentu diputuskannya kebijakan publik antara lain struktur birokrasi, SDM, disposisi, dan komunikasi. Dikatakan sebagai faktor penentu karena struktur birokrasi yang terlalu panjang akan menimbulkan birokrasi yang rumit dan komplek hal ini akan menyebabkan jalannya organisasi tidak fleksibel dan melemahkan pengawasan. Sumber daya yang bagus dan berkualitas akan mempermudah dan mempercepat dalam melaksanakan kebijakan. Disposisi yang baik dan jelas akan memudahkan pelaksana kebijakan dalam menjalankan tugas. Komunikasi yang baik harus dibangun dengan cara komunikasi dua arah, agar semua informasi dapat diterima dengan baik dan cepat mendapat respon balik oleh implementor. 


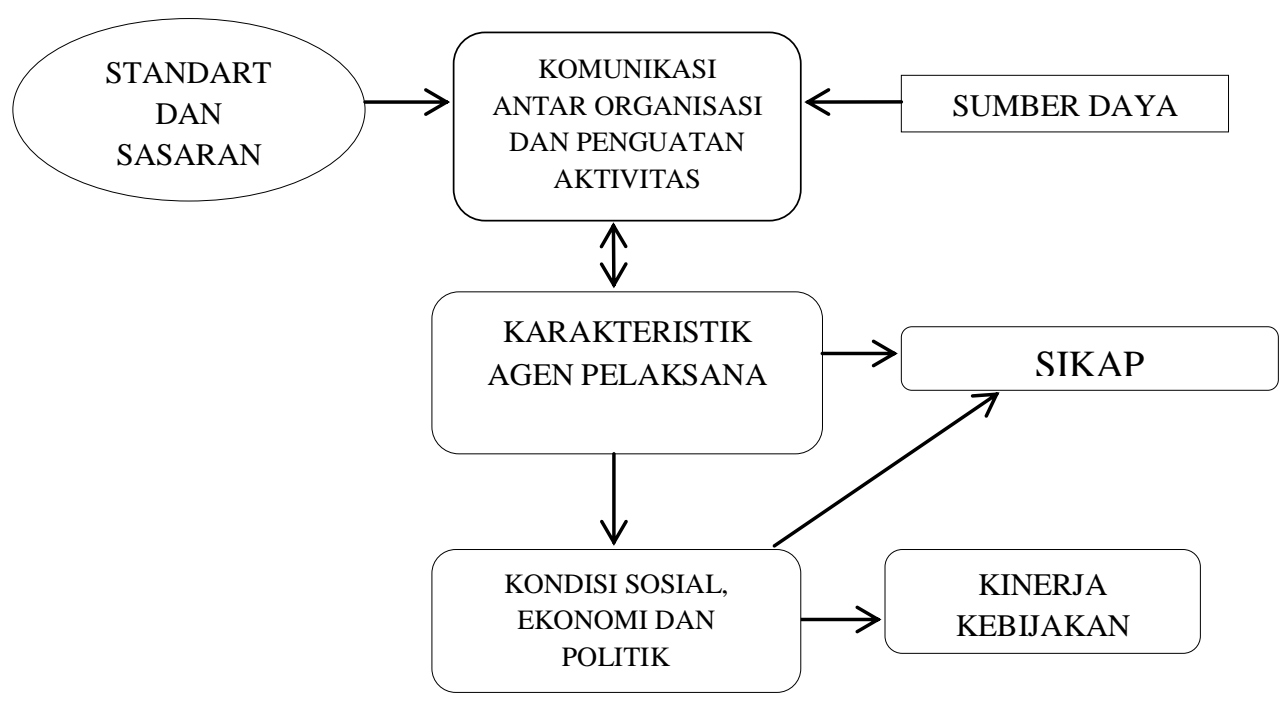

Gambar 2. Model Implementasi Kebijakan menurut Van Meter dan Van Horn dalam Subarsono (2005)

Dari Model Implementasi Kebijakan menurut Van Meter dan Van Horn yang terlihat dalam Gambar 2 dapat dijelaskan bahwa komunikasi antar organisasi dan penguatan aktivitas yang akan dilakukan dipengaruhi oleh strandart dan sasaran kebijakan yang telah ditentukan serta sumber daya yang tersedia. Namun, komunikasi dan penguatan aktivitas dimaksud juga saling mempengaruhi dengan karakteristik agen pelaksananya. Hubungan dua arah ini tidak dapat dihindarkan karena sama-sama menentukan.
Selanjutnya, karakteristik agen pelaksana akan menentukan seperti apa sikap pelaksana di lapangan dalam mengimplementasikan kebijakan. Selain itu, karakteristik dimaksud akan kondisi sosial, ekonomi, dan politik sebagai dampak langsung cara kebijakan diimplementasikan. Kemudian, kondisi sosial, ekonomi, dan politik yang ada akan menentukan sikap pelaksana dalam menjalankan kebijakan di lapangan. Sebagai hasil akhir, kondisi tersebut menunjukkan kinerja kebijakan. 


\section{METODE PENELITIAN}

Penggunaan metode penelitian berfungsi sebagai pemandu peneliti bagaimana melakukan penelitian tersebut. Pada dasarnya seseorang melakukan penelitian bertujuan untuk memahami kejadian, situasi atau keadaan khusus yang terjadi di dalam masyarakat. Selain itu penelitian juga bertujuan untuk mencari jalan keluar atau pemecahan masalah serta kegunaan tertentu. Jadi metode penelitian harus dilakukan dengan baik dan benar agar hasilnya pun dapat diterima secara ilmiah.

Jenis penelitian yang dilakukan adalah kualitatif. Metode kualitatif digunakan dengan pertimbangan bahwa peneliti bermaksud untuk mendeskripsikan atau memperoleh gambaran secara leluasa tentang Implementasi Peraturan Daerah Kabupaten Jember Nomor 6 Tahun 2008. Metode kualitatif adalah prosedur penelitian yang menghasilkan data deskriptif berupa kata-kata tertulis atau lisan dari orang-orang dan perilaku yang dapat diamati (Moleong, 2005:4).

$$
\text { Pendapat lainnya }
$$

mengungkapkan bahwa metode penelitian kualitatif adalah metode penelitian yang digunakan untuk meneliti kondisi obyek yang alamiah, dimana peneliti sebagai instrumen kunci, teknik pengumpulan data dilakukan secara triangulasi analisis data bersifat induktif, dan hasil penelitian kualitatif lebih menekankan pada makna dan pada generalisasi (Sugiyono, 2005:1). Adapun pendekatan yang digunakan dalam penelitian ini adalah pendekatan kualitatif fenomenologis. Dikatakan demikian karena pendekatan kualitatif pada penelitian ini mempunyai ciri-ciri antara lain mempunyai setting yang aktual, peneliti adalah instrumen kunci, data biasanya bersifat deskriptif, menekankan kepada proses analisis datanya bersifat induktif, dan meaning (pemaknaan) tiap even adalah merupakan perhatian yang esensial dalam penelitian kualitatif (Bogdan dan Biklen. 1982). Dikatakan fenomenologi karena sesuai dengan tujuan penelitian yaitu mendeskripsikan peristiwa sosial. Selain itu karena dapat mengungkapkan peristiwa-peristiwa 
riil di lapangan. Juga dapat mengungkapkan nilai-nilai yang tersembunyi (hidden value), lebih peka terhadap informasi-informasi yang bersifat deskriptif dan berusaha mempertahankan keutuhan obyek yang diteliti. Lebih tegasnya peneliti akan menemukan jawaban yang logis terhadap apa yang sedang menjadi pusat perhatian dalam penelitian (Bungin, 2007).

\section{HASIL PENELITIAN DAN PEMBAHASAN}

Kecamatan Kaliwates secara administratif dibagi menjadi 7 kelurahan. antara lain Kelurahan Mangli, Sempusari, Kaliwates, Tegal Besar, Jember Kidul, Kepatihan dan Kebon Agung. Jumlah penduduk tahun 2014 sebanyak 114.525 jiwa terdiri dari perempuan sebanyak 58.943 jiwa dan laki-laki sebanyak 55.582 jiwa. Sedangkan penduduk usia produktif yaitu antara usia 1564 tahun sebesar 76.655 jiwa, angkatan kerja yang begitu banyak jelas membutuhkan lapangan pekerjaan yang luas selain sektor pertanian yaitu sektor perdagangan. Sektor perdagangan maju pesat disebabkan adanya pusat perdagangan baru dan besar antara lain adanya Johar Plasa, Mutiara Plasa, Pasar Tanjung, Carrefor, Roxy Square, Nico, Rien Collection. Hal ini menjadi sebab pertumbuhan di sektor lainnya yaitu sektor informal yang biasa kita sebut dengan PKL. Keadaan ini sudah menjadi suatu hal yang saling berkaitan antara keberadaan pusatpusat perbelanjaan dengan pertumbuhan PKL disekitar pusat perbelanjaan tersebut.

Keberadaan PKL semakin meningkat di Kecamatan Kaliwates yaitu antara tahun 2013 sampai tahun 2014 mengalami pertambahan sebanyak 55 orang PKL, namun dalam tahun 2014 sampai tahun 2015 mengalami penurunan sebanyak 208 PKL. Ini semua disebabkan adanya relokasi PKL di seputaran pasar tanjung yang dilakukan aparat Satpol PP Kabupaten Jember.

Peningkatan jumlah PKL bisa juga disebabkan adanya 1 (satu) perguruan tinggi negeri dan 2 (dua) swasta, dengan jumlah mahasiswa 
9.091 orang, mereka ada yang berasal dari luar kota Jember dan indekost di Jember, Kecamatan Sumbersari terdiri dari 7 kelurahan yaitu Kelurahan Kranjingan, Kelurahan Wirolegi, Kelurahan Karangrejo, Kelurahan Kebonsari, Kelurahan Sumbersari, Kelurahan Tegalgede dan Kelurahan Antirogo dengan jumlah penduduk sebanyak 129.302 jiwa terdiri dari perempuan sebanyak 65.957 jiwa dan laki-laki sebanyak 62.979 jiwa di tahun 2013 . Dilain pihak jumlah penduduk yang terbanyak berada pada kelompok umur 20-24 tahun yang merupakan umur produktif yaitu sebanyak 16.662 jiwa. Sedangkan lapangan pekerjaan tidak mencukupi, hal ini menyebabkan terjadi perubahan mata pencaharian utama penduduk ke sektor lainnya yaitu sektor pedagangan dan sektor informal lainnya sebagai PKL.

PKL di kecamatan Sumbersari dari tahun 2013 sampai tahun 2015 bertambah sebanyak 116 orang, terutama di seputaran kampus yaitu bertambah sebanyak 62 orang PKL, ini disebabkan adanya Perguruan Tinggi Negeri dan Swasta sebanyak
8 buah antara lain Universitas Jember (Unej), Universitas Muhammadiyah (Unmuh), Sekolah Tinggi Ilmu Ekonomi (STIE) Mandala, Universitas Moh. Sroeji (Moser), IKIP PGRI, POLIJE, Akademi Akutansi PGRI dan Akademi Pariwisata Unmuh. Keadaan inilah yang memunculkan kreativitas orang-orang seputaran kampus maupun orang-orang luar kecamatan Sumbersari untuk berjualan makanan dan minuman untuk memenuhi segala kebutuhan para mahasiswa.

Kecamatan Patrang secara administratif terbagi dalam 8 Kelurahan, yaitu Kelurahan Gebang, Jember Lor, Patrang, Baratan, Bintoro, Slawu, Jumerto dan Banjarsengon, dengan jumlah penduduk tahun 2014 sejumlah 96.732 jiwa, sedangkan usia produktif yaitu antara usia 15-64 tahun sebesar 89.605 jiwa. Angkatan kerja yang begitu banyak jelas membutuhkan lapangan pekerjaan, sedangkan lapangan pekerjaan tidak tersedia sehingga mereka beralih ke sektor informal 
yang tidak membutuhkan modal yang besar yaitu menjadi PKL.

Keberadaan PKL semakin meningkat dari 199 orang ditahun 2013 menjadi 245 ditahun 2015, jadi bertambah sebanyak 46 orang, terutama di yaitu di Jalan Panglima Sudirman, Jalan Dr. Soebandi, Jalan Kenanga, dan Jalan Kaca Piring. Bertambah PKL ini disebabkan adanya Rumah Sakit Umum Dr. Soebandi, jalan utama yang banyak dilalui oleh pembeli dan adanya perguruan tinggi swasta sebanyak 2 buah yaitu Akademi Kebidanan dan Sekolah Tinggi Pertanian.

Untuk mendapatkan data yang akurat tentang PKL di tiga kecamatan kota yaitu kecamatan Kaliwates, kecamatan Sumbersari dan kecamatan Patrang, maka peneliti perlu untuk membandingkan jumlah PKL di tiga kecamatan kota tersebut guna memperoleh perbandingan yang jelas dan akurat yaitu data PKL mulai tahun 2013 sampai dengan tahun 2015.

Tabel 1. Data Jumlah PKL di Kabupaten Jember (Kecamatan Kota) Tahun 2013

\begin{tabular}{|l|l|c|c|c|c|}
\hline \multirow{2}{*}{ No } & \multicolumn{1}{|c}{ Lokasi } & $\begin{array}{c}\text { Tahun } \\
\mathbf{2 0 1 3}\end{array}$ & $\begin{array}{c}\text { Tahun } \\
\mathbf{2 0 1 4}\end{array}$ & $\begin{array}{c}\text { Tahun } \\
\mathbf{2 0 1 5}\end{array}$ & \multirow{2}{*}{ Persentase } \\
\hline 1. & Kecamatan Kaliwates & 499 & 554 & 346 & $18,1 \%$ \\
\hline 2. & Kecamatan Sumbersari & 496 & 551 & 612 & $10,47 \%$ \\
\hline 3. & Kecamatan Patrang & 199 & 221 & 245 & $10,36 \%$ \\
\hline
\end{tabular}

Sumber: diolah dari laporan kecamatan dan Satpol PP Kabupaten Jember (2015)

Seperti yang terlihat dari Tabel

1 diatas dapat dibandingkan jumlah PKL dari tahun 2013 hingga tahun 2015 jumlahnya cenderung mengalami peningkatan yang cukup signifikan, terutama di dua kecamatan kota yaitu Kecamatan Sumbersari dan Kecamatan Patrang. Sedangkan PKL di Kecamatan Kaliwates menurun, disebabkan adanya penertiban yang dilakukan oleh aparat Satpol PP disekitar Pasar Tanjung (Jalan Dr. Wahidin, Jalan Samanhudi, dan Jalan Untung Suropati) dan telah direlokasi ke Pasar Bungur, Pasar Tegalbesar, Pasar Sukorejo, Pasar Gebang dan Pasar Kreongan.

Peningkatan jumlah PKL yang cukup drastis terjadi di kecamatan Sumbersari dari 496 PKL di tahun 2013 menjadi 612 PKL di tahun 
2015, kenaikan sebesar 116 PKL atau sebesar 10,47 \%. Hal ini disebabkan adanya peningkatan angkatan kerja yang terus bertambah sedangkan lapangan pekerjaan tidak memadai sehingga mereka memilih bekerja dijalur informal menjadi seorang PKL. Sektor informal menjadi pilihan karena tidak membutuhkan modal yang besar dan bisa juga dengan modal sendiri dan tidak membutuhkan tempat yang permanen. Peningkatan jumlah PKL bisa juga disebabkan oleh banyaknya perguruan tinggi di kecamatan Sumbersari yang disertai dengan banyaknya mahasiswa yang datang dari luar kabupaten Jember, sehingga mereka indekost atau menyewa

Tabel 2. Data Perguruan Tinggi dan Jumlah Mahasiswa di Tiga Wilayah

Kecamatan Kota s/d Tahun 2015

\begin{tabular}{|l|l|c|c|c|}
\hline No & \multicolumn{1}{|c|}{ Lokasi } & $\begin{array}{c}\text { Jumlah } \\
\text { Perguruan Tinggi }\end{array}$ & $\begin{array}{c}\text { Jumlah } \\
\text { Mahasiswa }\end{array}$ & Persentase \\
\hline 1. & Kecamatan Kaliwates & 3 & 9.091 & 13,06 \\
\hline 2. & Kecamatan Sumbersari & 8 & 59.626 & 85,68 \\
\hline 3. & Kecamatan Patrang & 2 & 878 & 1,26 \\
\hline \multicolumn{2}{r|}{ Jumlah Keseluruhan } & 13 & 69.595 & 100 \\
\hline
\end{tabular}

Sumber: Kabupaten Jember dalam angka (2015)

Melanjutkan analisa pada tabel sebelumnya tentang jumlah PKL yang cenderung meningkat, maka Tabel 2 menunjukkan salah satu sebab mengapa PKL cenderung rumah untuk tempat tinggal. Keberadaan mahasiswa yang indikost atau menyewa rumah tidak mempunyai waktu luang untuk memasak makanannya sendiri yang pada akhirnya mereka membeli makanan diluar. Peluang inilah yang dimanfaatkan oleh PKL untuk berjualan diseputar kampus.

Berkaitan dengan jumlah PKL yang terus meningkat, salah satu sebab karena adanya perguruan tinggi baik negeri maupun swasta yang ada di tiga kecamatan kota yaitu Kecamatan Kaliwates, Kecamatan Sumbersari dan Kecamatan Patrang, maka disajikan data tabel sebagai berikut: mengalami peningkatan karena adanya perguruan tinggi baik negeri maupun swasta yang ada di tiga kecamatan kota. Kalau kita lihat dari tiga kecamatan kota yang paling 
banyak perguruan tingginya adalah kecamatan Sumbersari sebanyak 8 perguruan tinggi antara lain Universitas Jember (Unej), POLIJE (PTN) dan Universitas Muhammadiyah (Unmuh), Sekolah Tinggi Ilmu Ekonomi (STIE) Mandala, Universitas Moh. Sroeji (Moser), IKIP PGRI, Akademi Akutansi PGRI dan Akademi Pariwisata Unmuh (PTS) dengan jumlah mahasiswa sebanyak 59.626 orang atau sebesar $85,68 \%$ dan yang terbanyak adalah mahasiswa dari Universitas Jember sebanyak 32.627 orang atau sebesar $54,72 \%$ dengan perincian mahasiswa asal Jember sebanyak 10.784 orang atau sebesar $33,05 \%$ dan yang berasal dari luar Jember sebanyak 21.843 orang atau sebesar $66,95 \%$.

Berdasarkan data tersebut dapat dianalisa bahwa mahasiswa dari luar kabupaten Jember jelas memerlukan tempat tinggal selama mereka ada di Jember, yaitu dengan jalan indekost atau menyewa rumah, mereka tidak memasak makanannya sendiri karena sibuk, tidak ada waktu dan mereka memilih praktisnya saja dengan jalan membeli, jadi mereka membutuhkan makan tiga kali sehari. Keadaan seperti ini menjadi peluang bagi para PKL untuk berjualan makanan siap saji, murah dan terjangkau oleh mahasiswa di seputaran kampus. Oleh sebab itu PKL di seputaran kampus Unej selalu bertambah setiap tahunnya dan keadaan ini kalau tidak ditata dan ditertibkan akan banyak menimbulkan gesekan kepentingan. PKL kebanyakan berjualan dipingir jalan yang memakan bahu jalan, dengan pertimbangan mudah dijangkau oleh para mahasiswa tanpa turun dari kendaraannya dan hal ini membahayakan keselamatan para pembelinya dan pada akhirnya menimbulkan kemacetan lalu lintas.

Pada pinsipnya pendukung utama keberhasilan program dan kegiatan dalam proses komunikasi adalah adanya regulasi atau aturan yang dapat menjawab dinamika masyarakat, serta adanya solusi yang dapat mengakomodir kepentingan pemerintah, masyarakat serta PKL. Komunikasi dalam implementasi kebijakan mencakup beberapa dimensi penting yaitu tranformasi informasi (transimisi), kejelasan 
informasi (clarity) dan konsistensi informasi (consistency). Aspek komunikasi akan memuat berbagai berbagai macam kejadian yang diamati penulis dilapangan terkait dengan implementasi peraturan daerah Kabupaten Jember tentang PKL.

Para PKL di tiga kecamatan kota yaitu Kecamatan Kaliwates, Kecamatan Sumbersari dan Kecamatan Patrang sudah memahami dan mengerti akan tugas Satpol PP dalam melakukan komunikasi dengan mereka, namun

\section{KESIMPULAN DAN SARAN}

Implementasi Peraturan Daerah Kabupaten Jember Nomor 6 Tahun 2008 tentang PKL dikatakan kurang berhasil, karena masih ada PKL yang kembali ketempat semula setelah direokasi ataupun mereka tidak mau pindah secara sukarela meskipun sudah disediakan tempat relokasinya sehingga memaksa aparat Satpol PP beserta Tim Penataan PKL mengambil langkah represif.

Hasil temuan dari kurang berhasilnya Implementasi Peraturan Daerah Kabupaten Jember Nomor 6 masih ada atau tetap melanggar aturan itu lebih disebabkan oleh kesadaran mereka akan ketertiban, keindahan dan kebersihan kota sangat kurang sekali, dan bukan berarti proses komunikasi tidak berhasil karena setidaknya dengan komunikasi yang dilakukan oleh aparat Satpol PP dapat mencegah adanya pelanggar baru, menggurangi pelanggar yang ada. Hal ini menjelaskan bahwa para PKL sebenarnya mengetahui bahkan memahami peraturan daerah yang ada.

Tahun 2008 tentang PKL dan untuk menjelaskan permasalahan itu dengan menggunakan teori Model Kebijakan Implementasi menurut George Edward III dan Model Implementasi Kebijakan menurut Van Meter dan Van Horn dapat dijelaskan sebagai berikut:

1. Dalam aspek komunikasi menunjukkan sosialisasi sudah dilakukan secara optimal oleh aparat Satpol PP Kabupaten Jember, namun sering kali sudah apriori atau ada kecurigaan dari 
PKL. Jadi komunikasi tidak terjalin dengan baik antara aparat Satpol PP, maunya menyampaikan penertiban dengan baik, tetapi para PKL sudah melakukan tindakan yang berakibat terjadi bentrokan.

2. Dalam aspek SDM, aparat Satpol PP dari segi tingkat pendidikan kurang, karena masih ada yang lulusan tingkat SD dan SMP yang mana ini tidak sesuai dengan kualifikasi yang tertuang di Peraturan Pemerintah Nomor 6 Tahun 2010 yang seharusnya minimal pendidikan SMA. Keadaan seperti ini terjadi karena Satpol PP tidak merekrut pegawai sendiri, melainkan direkrut oleh Badan Kepegawaian Daerah Kabupaten Jember.

3. Dalam aspek karakteristik agen/badan-badan pelaksana difokuskan pada aparatur Satpol yaitu Kasatpol PP. Kasatpol PP sudah mendapat dukungan dari pembuat kebijakan yaitu Bupati dan DPRD secara otomatis dengan dikeluarkannya Peraturan Daerah Kabupaten Jember
Nomor 6 Tahun 2008 tentang PKL. Namun kenyataan dilapangan masih saja ada kendala- kendala yang dihadapi oleh aparat Satpol PP dalam menjalankan tugas.

4. Dalam aspek kondisi sosial, ekonomi dan politik yang berkaitan dengan kondisi lingkungan, kalau dilihat dari fakta yang ada tingkat potensi konflik sosial kemasyarakatan di Kabupaten Jember bisa dibilang kondusif. Namun yang menjadi penyebab PKL berjualan bukan karena faktor aman dan tidak aman, melainkan karena tuntutan ekonomi atau masalah perut.

Saran yang akan peneliti sampaikan berdasarkan kesimpulan yang telah diuraikan berkenaan dengan hasil penelitian yang telah dilakukan yaitu Implementasi Peraturan Daerah Kabupaten Jember Nomor 6 Tahun 2008 tentang PKL, maka saran-saran yang peneliti diberikan sebagai berikut:

1. Bagi Pemerintah Daerah

Sebelum melakukan penataan dan penertiban PKL, ada tiga hal yang harus disinergikan antara 
beberapa organisasi perangkat daerah, karena masalah PKL bukan hanya masalah Satpol PP saja melainkan ada beberapa dinas yang saling berkaitan. Tiga hal yang harus disiapkan sebelum melakukan penataan dan penertiban pedagang kaki lima yaitu: a) Ada penataannya yaitu menyediakan tempat relokasi dengan segala aksesnya, yang menjadi tanggung jawab Dinas Cipta Karya dan Tata Ruang; b) Ada pemberdayaan yaitu memberikan pelatihan-pelatihan kepada PKL agar dagangan mereka lebih menarik tampilan maupun rasanya, ini menjadi tanggung jawab Dinas Perindustrian dan Perdagangan; dan c) Setelah kedua hal tersebut dipenuhi baru ada penertiban, yang ini menjadi tugas Satpol PP. Kalau ketiga hal itu bisa disinergikan maka tidak akan ada lagi PKL yang akan kembali ketempat semula mereka berdagang.

2. Bagi Satuan Polisi Pamong Praja a. Bila mana sudah dilakukan penataan hendaknya faktor pengawasan dengan jalan patroli rutin harus lebih ditingkatkan dan dilakukan secara berkesinambungan.

b. Bila ada satu PKL yang tumbuh dan menempati area publik, hendaknya langsung ditertibkan agar tidak menjadi beban dikemudian hari.

3. Bagi Persatuan Pedagang

a. Hendaknya selalu disiplin dan mentaati pada peraturan yang berlaku.

b. Selalu mencari rejeki dengan cara yang benar dan jalan yang benar tanpa menimbulkan masalah bagi masyarakat.

c. Pendewasaan cara berpikir masyarakat modern yang selalu taat peraturan dan menjunjung tinggi hak-hak orang lain.

4. Bagi Masyarakat Hendaknya jangan membeli pada PKL yang berjualan di area publik, agar menjadi pelajaran bagi para PKL, bahwa mereka itu salah dan melanggar peraturan yang ada. 


\section{DAFTAR PUSTAKA}

Agustino, Leo. 2006. Politik dan Kebijakan Publik. Bandung: AIPI.

Alisyahbana. 2005. Marginalisasi Sektor Informal Perkotaan. Surabaya: ITS Press.

Dwijowijoto, Riant Nugroho. 2004. Kebijakan Publik Formulasi, Implementasi, dan Evaluasi. Jakarta: Gramedia.

2008.

Public Policy. Jakarta: PT. Elexmedia Komputindo.

Kartono, dkk. 1980. Pedagang Kaki Lima. Bandung: Universitas Katholik Parahiyangan.

Manning, Chris dan Tajuddin Noer Effendi (eds.). 2001. Urbanisasi, Pengangguran dan Sektor Informal di Kota. Jakarta: Gramedia.

Mazumdar, Dipak. 1985. "Sektor Informal dan Kota di Dunia Ketiga", dalam Manning dan Tajuddin Noer Effendi (eds.), Urbanisasi, Pengangguran dan Sektor Informal di Kota. Jakarta: Gramedia.

R, Nugroho. 2005. Public Policy. Jakarta: Gramedia.
Soehino. 1998. Hukum Tata Negara (Penyusunan dan Penetapan Peraturan Daerah). Yogyakarta: Liberty.

Subarsono, AG. 2005. Analisis Kebijakan Publik (Konsep, Teori, dan Aplikasi). Yogyakarta: Pustaka Pelajar.

Sugiyono. 2005. Memahami Penelitian Kualitatif. Bandung: Alfabeta.

Sunggono, Bambang. 1994. Hukum dan Kebijakan Administrasi Publik. Jakarta: Sinar Grafika.

Susanto. 2013. Masalah Pedagang Kaki Lima di Bandung dan penertibannya melalui operasi Tibum 1980. Bandung: Universitas Katolik Parahyangan.

Wahab, Solichin Abdul. 1997. Analisis Kebijaksanaan dari Formulasi ke Implementasi Kebijakan Negara. Jakarta: Bumi Aksara.

Analisis Kebijaksanaan. Jakarta: Bumi Aksara.

Winarno, Budi. 2002. Kebijakan dan Proses Kebijakan Publik. Yogyakarta: Media Pressindo. 